\title{
Crystal structure transformation of $\mathrm{TiO}_{2}$ in presence of $\mathrm{Fe}_{2} \mathrm{O}_{3}$ and $\mathrm{NiO}$ in air atmosphere
}

\author{
S RIYAS, V AHMED YASIR and P N MOHAN DAS* \\ Regional Research Laboratory, Thiruvananthapuram 695 019, India
}

MS received 30 March 2001; revised 11 October 2001

\begin{abstract}
TiO}_{2}$ is produced and marketed in two main grades viz. anatase and rutile. Both anatase and rutile have their own pigmentry properties and hence cannot be substituted by each other. Pure anatase on heating at higher temperatures undergoes crystallographic rearrangement to form rutile. This transformation in presence of $\mathrm{NiO}$ and $\mathrm{Fe}_{2} \mathrm{O}_{3}$ under air atmosphere was studied using XRD and SEM. The transformation temperature was found to be reduced much in presence of $\mathrm{NiO}$ and $\mathrm{Fe}_{2} \mathrm{O}_{3}$ and the extent of lowering was higher for $\mathrm{NiO}$ than $\mathrm{Fe}_{2} \mathrm{O}_{3}$. The activation energy for this transformation was also calculated. The method of preparation had major influence on the transformation.
\end{abstract}

Keywords. Anatase; rutile; transformation; crystallographic rearrangement; activation energy.

\section{Introduction}

$\mathrm{TiO}_{2}$ is the stable form of titanium. It is also one of the top 20 inorganic chemicals of industrial importance and is an important pigment material used (A Status report prepared under the National Register of Foreign Collaborations, Govt. of India 1993). It exists in three different forms; anatase, rutile and brookite. Rutile is the stable form while anatase and brookite are meta stable. Anatase on heating transforms irreversibly to rutile. This transformation does not have a transformation temperature since there is no phase equilibrium involved (Gennari and Pasquevich 1998). Therefore, anatase to rutile transformation temperature varies, which strongly depends on many factors such as presence of impurity, deviation of stoichiometry, surface area, particle size, atmosphere etc (Yoganarasimhan and Rao 1962).

Yoganarasimhan and Rao (1962) have reported that sulphate ions have pronounced inhibiting action on anataserutile transformation. They studied the transformation in anatase prepared by the hydrolysis of titanium sulphate and found that transformation occurs at higher temperature than that for pure anatase. The rate of transformation of spectroscopically pure anatase is exponential with activation energy of $\sim 90 \mathrm{k} . \mathrm{cal} / \mathrm{mol}$ and the transformation temperature $400-1000^{\circ} \mathrm{C}$. Impurities having inhibiting action are chloride, sulphate, flouride (Rao et al 1959; Yoganarasimhan and Rao 1962), whereas transition metal oxides like $\mathrm{Fe}_{2} \mathrm{O}_{3}, \mathrm{CuO}, \mathrm{MnO}_{2}$ etc have accelerating power on anatase-rutile transformation (Shannon and Pask 1965; Mackenzie 1975). It has been

\footnotetext{
*Author for correspondence
}

revealed that ions increasing the oxygen vacancy concentration in $\mathrm{TiO}_{2}$ lattice will accelerate the transformation (Shannon and Pask 1965).

Since during anatase-rutile transformation, rupture of some of the $\mathrm{Ti}-\mathrm{O}$ bonds in anatase occurs to form a distorted octahedral arrangement of each tetragonal structure, which causes an increase in density, decrease in cell volume, mechanical strain and decrease in surface area leading to an overall degradation in physical properties of anatase (Gennari and Pasquevich 1999).

In the present study, the anatase-rutile transformation in presence of $\mathrm{NiO}$ and $\mathrm{Fe}_{2} \mathrm{O}_{3}$ has been investigated. The activation energy of transformation is also calculated. The samples were prepared by two different methods, viz. co-precipitation and wet-impregnation, in order to investigate the influence of preparation method on this transformation. The kinetics of the transformation is also studied.

\section{Experimental}

\subsection{Materials}

Samples were prepared using $\mathrm{TiO}_{2}$ pulp (uncalcined pure hydrated $\mathrm{TiO}_{2}$ containing $78.6 \% \mathrm{TiO}_{2}$ ) obtained from a $\mathrm{TiO}_{2}$ manufacturing factory, Travancore Titanium Products Ltd. Thiruvananthapuram, India, ferric nitrate (A.R. S.D. Fine Chem. Ltd) and nickel nitrate (A.R. S.D. Fine Chem. Ltd).

\subsection{Methods of preparation}

2.2a Preparation of $\mathrm{Fe}_{2} \mathrm{O}_{3} / \mathrm{TiO}_{2}$ : The samples were prepared by two methods, viz. co-precipitation and wetimpregnation. 
2.2b Co-precipitation using hydrazine hydrate: $11.45 \mathrm{~g}$ of pure hydrous $\mathrm{TiO}_{2}$ which contained $\mathrm{TiO}_{2}$ (anatase) $(8 \mathrm{~g})$ and ammonium sulphate $(160 \mathrm{~g})$ were taken in a $250 \mathrm{ml}$ beaker. $200 \mathrm{ml}$ conc. $\mathrm{H}_{2} \mathrm{SO}_{4}$ was added and heated till a clear solution was obtained. It was then cooled and diluted to about $11.5 .05 \mathrm{~g}$ ferric nitrate dissolved in $25 \mathrm{ml}$ distilled water was also added. The mixture was stirred well. Titanium and iron were then precipitated together by adding hydrazine hydrate till $\mathrm{pH}$ was 9 . The precipitate was decanted, washed with distilled water till the washings were free from sulphate ions and filtered using Whatman No. 42 filter paper. The precipitate was dried in an oven for $3 \mathrm{~h}$ at $110^{\circ} \mathrm{C}$, ground well, made into different portions in silica crucibles and calcined at different temperatures and time in muffle furnace.

2.2c Wet-impregnation: $11.45 \mathrm{~g}$ pure hydrous $\mathrm{TiO}_{2}$ was taken in a $250 \mathrm{ml}$ beaker. $5.05 \mathrm{~g}$ ferric nitrate dissolved in $25 \mathrm{ml}$ distilled water was added to it and made into a paste by mixing thoroughly. It was then dried in an oven for $3 \mathrm{~h}$ at $110^{\circ} \mathrm{C}$, ground well, made into different portions in silica crucibles and calcined at different temperatures and durations in a muffle furnace.

2.2d Preparation of $\mathrm{NiO}_{\mathrm{TiO}}$ : The samples were prepared by two methods viz. co-precipitation and wetimpregnation. 2.2e Co-precipitation using hydrazine hydrate: The procedure followed for the preparation was the same as given in the case of $\mathrm{Fe}_{2} \mathrm{O}_{3} / \mathrm{TiO}_{2}$ except that $8.1 \mathrm{~g}$ nickel nitrate was used in place of ferric nitrate.

2.2f Wet-impregnation: Preparation of $\mathrm{NiO} / \mathrm{TiO}_{2}$ was done using the same procedure as followed for $\mathrm{Fe}_{2} \mathrm{O}_{3} /$ $\mathrm{TiO}_{2}$ by adding $8.1 \mathrm{~g}$ nickel nitrate instead of ferric nitrate.

\section{Chemical analysis}

Chemical analysis of the samples was done as per the standard procedures available in literature (Kolthoff et al 1961, 1962). $\mathrm{TiO}_{2}$ was estimated using aluminium reduction method. $\mathrm{Fe}_{2} \mathrm{O}_{3}$ was estimated by titration against potassium dichromate after reduction with stannous chloride. Nickel was estimated gravimetrically with dimethyl glyoxime after precipitating out titania using ammonium hydroxide.

\section{X-ray diffraction studies}

The X-ray diffraction studies were carried out by the powder diffraction technique using a Philips X-ray
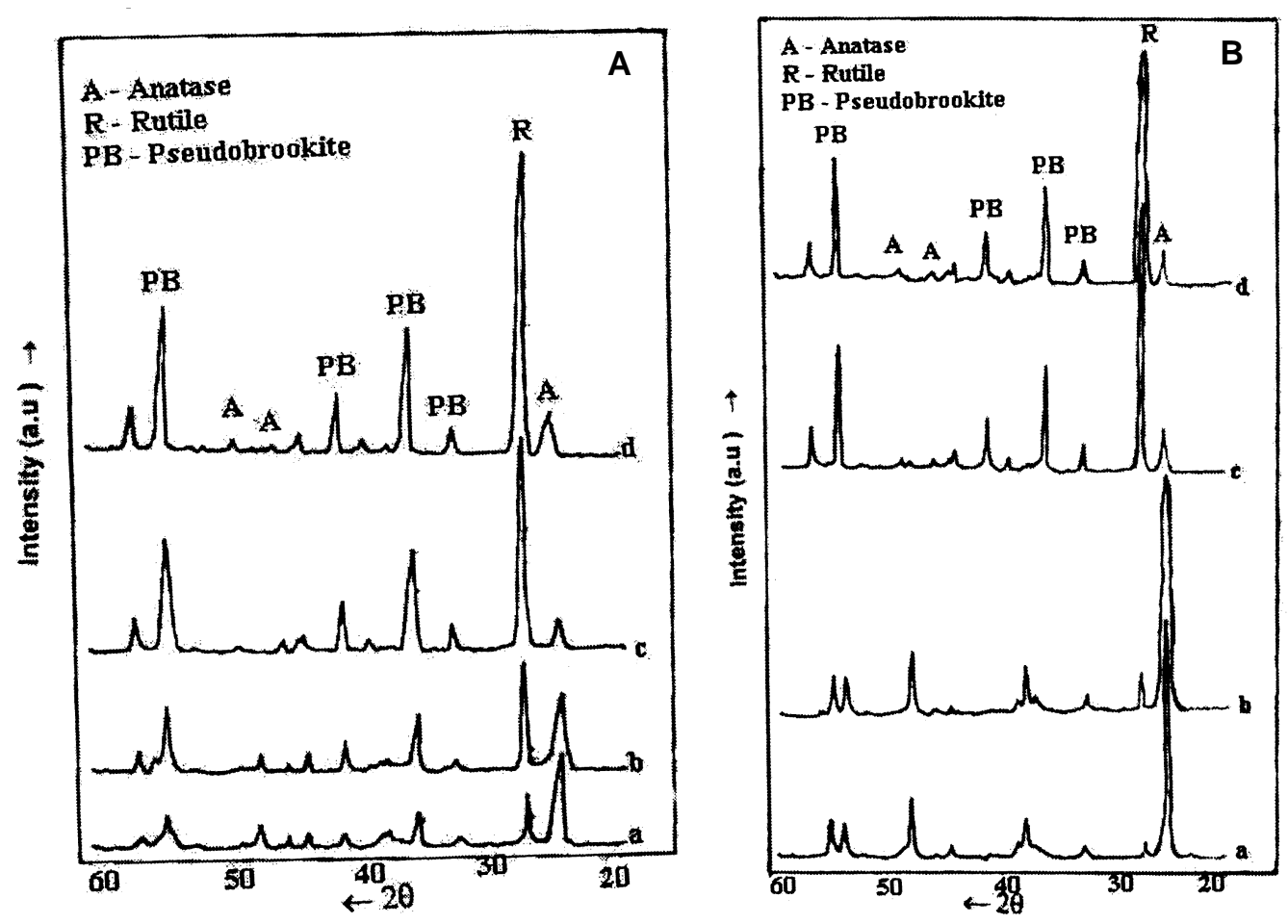

Figure 1. A. $\mathrm{XRD}$ patterns of co-precipitated $\mathrm{Fe}_{2} \mathrm{O}_{3} / \mathrm{TiO}_{2}$ samples calcined at a. $700^{\circ} \mathrm{C}$ for $6 \mathrm{~h}$, b. $700^{\circ} \mathrm{C}$ for $10 \mathrm{~h}$, c. $900^{\circ} \mathrm{C}$ for $6 \mathrm{~h}$ and d. $900^{\circ} \mathrm{C}$ for $10 \mathrm{~h}$ and $\mathbf{B}$. XRD patterns of wet-impregnated $\mathrm{Fe}_{2} \mathrm{O}_{3} / \mathrm{TiO}_{2}$ samples calcined at a. $700^{\circ} \mathrm{C}$ for $6 \mathrm{~h}$, b. $700^{\circ} \mathrm{C}$ for $10 \mathrm{~h}$, c. $900^{\circ} \mathrm{C}$ for $6 \mathrm{~h}$ and d. $900^{\circ} \mathrm{C}$ for $10 \mathrm{~h}$. 
diffractometer (PW, 1140) with $\mathrm{CuK} \alpha$ radiation with a wavelength of $1.5418 \AA$.

$\mathrm{X}$-ray diffraction of all the samples calcined at different temperatures and durations were done. In order to study the kinetics of anatase to rutile transformation,

Table 1a. Rutile \% formed on calcination of co-precipitated $\mathrm{Fe}_{2} \mathrm{O}_{3} / \mathrm{TiO}_{2}$ samples at different temperatures and time.

\begin{tabular}{lcc}
\hline $\begin{array}{l}\text { Temperature } \\
\left({ }^{\circ} \mathrm{C}\right)\end{array}$ & $\begin{array}{c}\text { Time of heating } \\
(\mathrm{h})\end{array}$ & $\begin{array}{c}\text { Rutile } \\
(\%)\end{array}$ \\
\hline 700 & 6 & $39 \cdot 3$ \\
700 & 8 & $60 \cdot 7$ \\
700 & 10 & $61 \cdot 3$ \\
800 & 6 & $64 \cdot 3$ \\
800 & 8 & $75 \cdot 5$ \\
800 & 10 & $76 \cdot 8$ \\
900 & 6 & $89 \cdot 2$ \\
900 & 8 & $92 \cdot 7$ \\
900 & 10 & $98 \cdot 7$ \\
\hline
\end{tabular}

Table 1b. Rutile \% formed on calcination of wet-impregnated $\mathrm{Fe}_{2} \mathrm{O}_{3} / \mathrm{TiO}_{2}$ samples at different temperatures and time.

\begin{tabular}{lcc}
\hline $\begin{array}{l}\text { Temperature } \\
\left({ }^{\circ} \mathrm{C}\right)\end{array}$ & $\begin{array}{c}\text { Time of heating } \\
(\mathrm{h})\end{array}$ & $\begin{array}{c}\text { Rutile } \\
(\%)\end{array}$ \\
\hline 750 & 6 & $22 \cdot 6$ \\
750 & 8 & $26 \cdot 4$ \\
750 & 10 & $28 \cdot 3$ \\
800 & 6 & $45 \cdot 3$ \\
800 & 8 & $48 \cdot 5$ \\
800 & 10 & $51 \cdot 8$ \\
900 & 6 & $89 \cdot 2$ \\
900 & 8 & $90 \cdot 3$ \\
900 & 10 & $91 \cdot 4$ \\
\hline
\end{tabular}

the percentage of rutile formed was calculated in each sample and the ' $d$ ' values were compared with the standard ASTM values.

For calculating percentage of rutile formed, the following equation was used (Gennari and Pasquevich 1998)

$$
\text { Percentage of rutile }=100 / 1+1 \cdot 26 I_{\mathrm{R}} / I_{\mathrm{A}},
$$

where $I_{\mathrm{A}}$ and $I_{\mathrm{R}}$ are the peak intensities of [101] and [110] planes of anatase and rutile, respectively.

\section{Scanning electron microscopic studies}

$0 \cdot 1 \mathrm{~g}$ of sample was taken in a test tube, $10 \mathrm{ml}$ of acetone was added and sonicated to disperse the particle. One drop of this solution was placed on a copper stud, dried in air, made conducting by gold (99\%) sputtering and was analysed using J.S.M-5600 instrument.

\section{Surface area measurement}

The surface area measurements were done using a GEMINI III 2375 Surface area analyser (Micro Meritics Instrument Corporation, USA) based on standard principle (Hiemenz 1986).

\section{Results and discussion}

\section{$7.1 \mathrm{Fe}_{2} \mathrm{O}_{3}$ doped $\mathrm{TiO}_{2}$}

Chemical analysis of $\mathrm{Fe}_{2} \mathrm{O}_{3} / \mathrm{TiO}_{2}$ samples showed that the $\mathrm{Fe}_{2} \mathrm{O}_{3}$ contents were $9 \cdot 10 \%$ and $10 \cdot 32 \%$ in coprecipitated and wet-impregnated samples, respectively. The $\mathrm{TiO}_{2}$ contents were 90.6 and $89.2 \%$, respectively. The XRD patterns of the co-precipitated and wet-
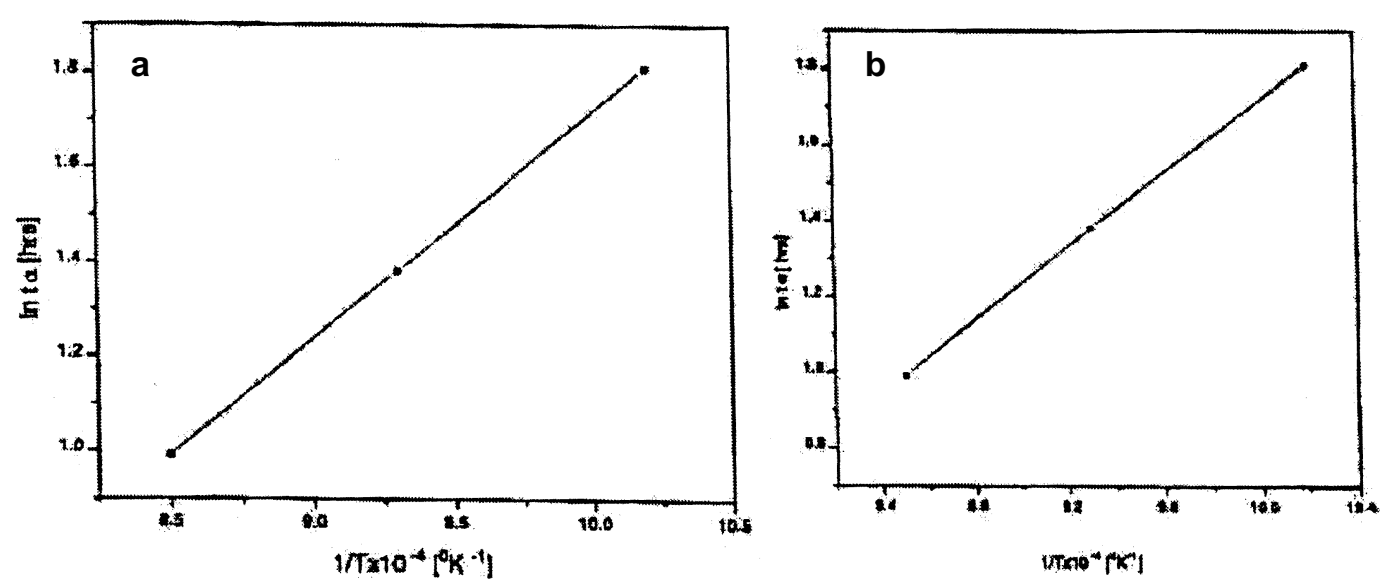

Figure 2. a. Plot of $\ln t \alpha$ against $1 / T$ for co-precipitated $\mathrm{Fe}_{2} \mathrm{O}_{3} / \mathrm{TiO}_{2}$ samples and b. plot of $\ln t \alpha$ against $1 / T$ for wet-impregnated $\mathrm{Fe}_{2} \mathrm{O}_{3} / \mathrm{TiO}_{2}$ samples. 
impregnated samples are shown in figures $1 \mathrm{~A}$ and $\mathrm{B}$, respectively.

In all the samples there were peaks corresponding to anatase, rutile and pseudo brookite while no peaks were found for $\alpha-\mathrm{Fe}_{2} \mathrm{O}_{3}$. It was obvious that $\mathrm{Fe}_{2} \mathrm{O}_{3}$ enhanced rutilation. In co-precipitated samples the enhancement was higher than that in wet-impregnated ones, since in co-precipitated samples there was uniform distribution of $\mathrm{Fe}_{2} \mathrm{O}_{3}$ as both were precipitated from a homogeneous solution.

It was found that in both the samples, rutilation increased with temperature. The conversion was different at different temperatures. In co-precipitated samples, this

Table 2. Surface area of $\mathrm{Fe}_{2} \mathrm{O}_{3} / \mathrm{TiO}_{2}$ samples prepared by co-precipitation and wet-impregnation.

\begin{tabular}{lcc}
\hline & \multicolumn{2}{c}{ Surface area $\left(\mathrm{m}^{2} / \mathrm{g}\right)$} \\
\cline { 2 - 3 } $\begin{array}{l}\text { Method of } \\
\text { preparation }\end{array}$ & $\begin{array}{c}\text { After calcination at } \\
900^{\circ} \mathrm{C} / 10 \mathrm{~h}\end{array}$ \\
\hline Co-precipitation & 251.8 & 2.48 \\
Wet-impregnation & 242.93 & 2.53 \\
\hline
\end{tabular}
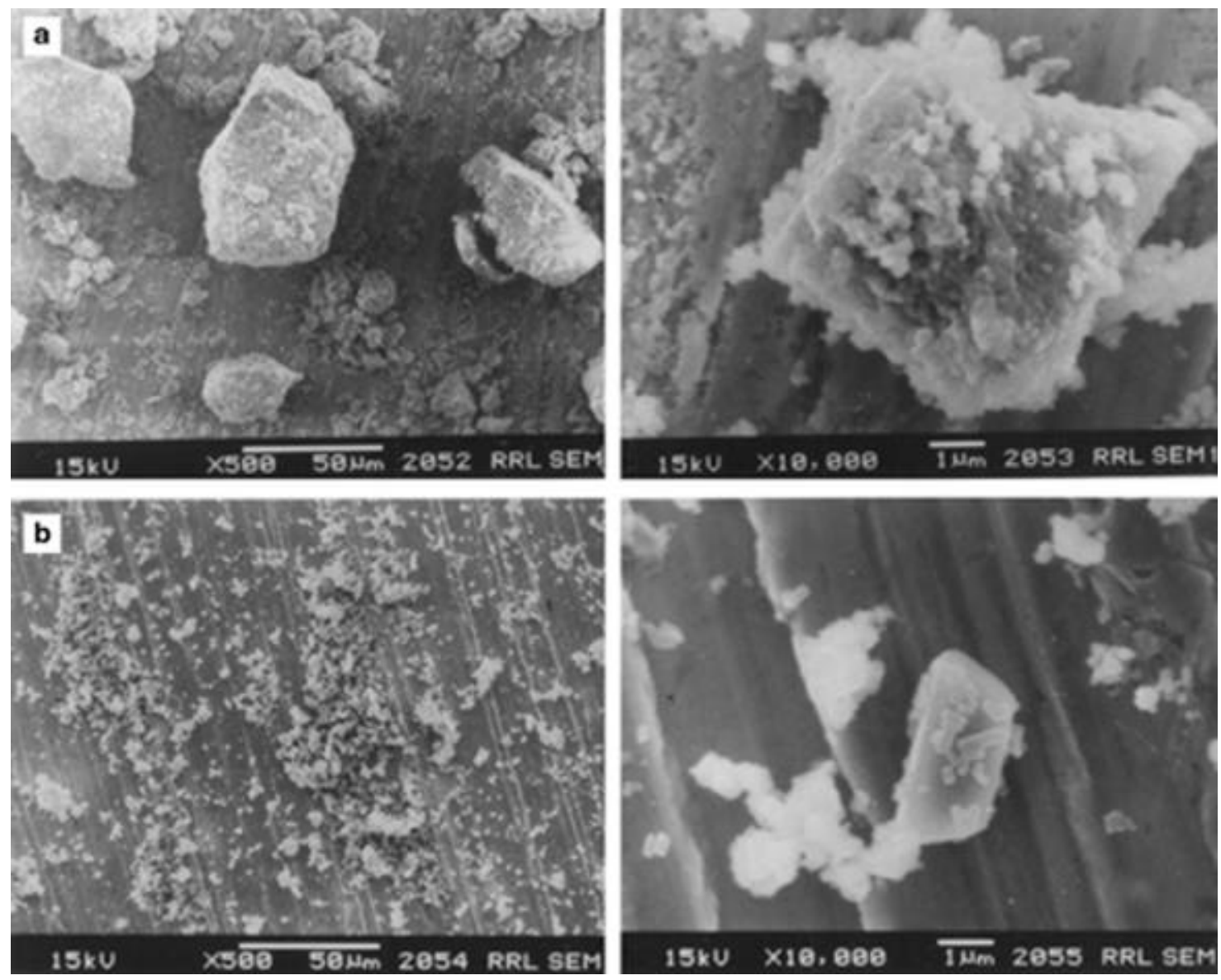

Figure 3. a. SEM of co-precipitated $\mathrm{Fe}_{2} \mathrm{O}_{3} / \mathrm{TiO}_{2}$ samples calcined at $900^{\circ} \mathrm{C}$ for $10 \mathrm{~h}$ and b. SEM of wetimpregnated $\mathrm{Fe}_{2} \mathrm{O}_{3} / \mathrm{TiO}_{2}$ samples calcined at $900^{\circ} \mathrm{C}$ for $10 \mathrm{~h}$. conversion was higher than that in wet-impregnated ones. The rutile percentage in both the above samples at different temperatures and durations were calculated and are shown in tables 1a and b, respectively.

The activation energy for anatase-rutile transformation, calculated from the slope of the plot shown in figures $2 \mathrm{a}$ and $\mathrm{b}$ gave a value of $10.9 \mathrm{k} . \mathrm{cal} / \mathrm{mol}$ for coprecipitated sample and $21.8 \mathrm{k} . \mathrm{cal} / \mathrm{mol}$ for wet-impregnated samples against a reported value of $90 \mathrm{k} . \mathrm{cal} / \mathrm{mol}$ for pure anatase (Gennari and Pasquevich 1998).

Hence $\mathrm{Fe}_{2} \mathrm{O}_{3}$ enhances rutilation by lowering activation energy. The lowering effect is higher for coprecipitated samples than that of wet-impregnated ones.

Surface area measurements showed that surface area of samples decreased sharply on calcination at $900^{\circ} \mathrm{C}$ for $10 \mathrm{~h}$ in both the samples due to rutilation as shown in table 2. The decrease was higher in co-precipitated samples because of higher rutile percentage.

Scanning electron micrographs of co-precipitated and wet-impregnated samples calcined at $900^{\circ} \mathrm{C}$ for $10 \mathrm{~h}$ are shown in figures $3 a$ and $b$.

It was found that the particles were very fine and much less agglomerated in wet-impregnated samples compared 

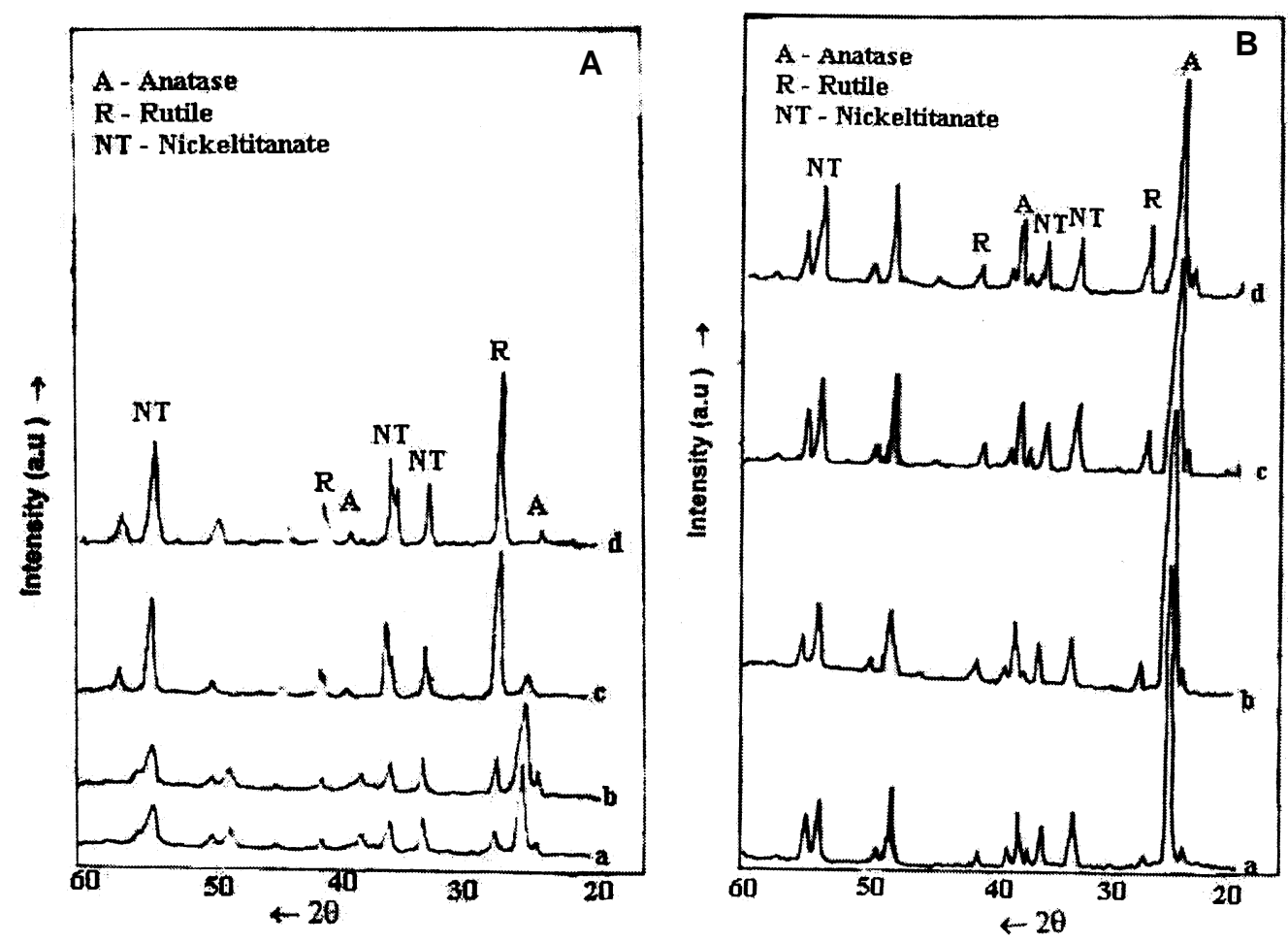

Figure 4. A. XRD patterns of co-precipitated $\mathrm{NiO} / \mathrm{TiO}_{2}$ samples calcined at a. $700^{\circ} \mathrm{C}$ for $4 \mathrm{~h}$, b. $700^{\circ} \mathrm{C}$ for $8 \mathrm{~h}$, c. $800^{\circ} \mathrm{C}$ for $4 \mathrm{~h}$ and d. $800^{\circ} \mathrm{C}$ for $8 \mathrm{~h}$ and $\mathbf{B}$. XRD patterns of wet-impregnated $\mathrm{NiO} / \mathrm{TiO}_{2}$ samples calcined at a. $750^{\circ} \mathrm{C}$ for $4 \mathrm{~h}$, b. $750^{\circ} \mathrm{C}$ for $8 \mathrm{~h}, \mathrm{c} .900^{\circ} \mathrm{C}$ for $4 \mathrm{~h}$ and d. $900^{\circ} \mathrm{C}$ for $8 \mathrm{~h}$.

Table 3a. Rutile \% formed on calcination of co-precipitated $\mathrm{NiO} / \mathrm{TiO}_{2}$ samples at different temperatures and time.

\begin{tabular}{lcc}
\hline $\begin{array}{l}\text { Temperature } \\
\left({ }^{\circ} \mathrm{C}\right)\end{array}$ & $\begin{array}{c}\text { Time of heating } \\
(\mathrm{h})\end{array}$ & $\begin{array}{c}\text { Rutile } \\
(\%)\end{array}$ \\
\hline 700 & 4 & $45 \cdot 6$ \\
700 & 6 & $50 \cdot 1$ \\
700 & 8 & $56 \cdot 3$ \\
750 & 4 & $68 \cdot 4$ \\
750 & 6 & $71 \cdot 2$ \\
750 & 8 & 74 \\
800 & 4 & $89 \cdot 1$ \\
800 & 6 & $91 \cdot 4$ \\
800 & 8 & $92 \cdot 5$ \\
\hline
\end{tabular}

to co-precipitated ones, which could be due to lower rutile $\%$. The particles in each sample prepared by the above two methods were different in size and shape. No individual $\mathrm{Fe}_{2} \mathrm{O}_{3}$ particles were seen in any of the micrographs. This is in agreement with XRD studies since there is no peak corresponding to $\mathrm{Fe}_{2} \mathrm{O}_{3}$ found in any of the XRD pattern.

From the above data it is clear that $\mathrm{Fe}_{2} \mathrm{O}_{3}$ enhances rutilation by lowering activation energy and the enhancement effect varies with method of preparation of samples. The changes in $\%$ of the $\mathrm{Fe}_{2} \mathrm{O}_{3}$ would change the
Table 3b. Rutile \% formed on calcination of wet-impregnated $\mathrm{NiO} / \mathrm{TiO}_{2}$ samples at different temperatures and time.

\begin{tabular}{lcc}
\hline $\begin{array}{l}\text { Temperature } \\
\left({ }^{\circ} \mathrm{C}\right)\end{array}$ & $\begin{array}{c}\text { Time of heating } \\
(\mathrm{h})\end{array}$ & $\begin{array}{c}\text { Rutile } \\
(\%)\end{array}$ \\
\hline 750 & 4 & $31 \cdot 5$ \\
750 & 6 & $54 \cdot 3$ \\
750 & 8 & $64 \cdot 1$ \\
800 & 4 & $62 \cdot 8$ \\
800 & 6 & $74 \cdot 2$ \\
800 & 8 & $80 \cdot 4$ \\
900 & 4 & $62 \cdot 2$ \\
900 & 6 & $83 \cdot 1$ \\
900 & 8 & $93 \cdot 5$ \\
\hline
\end{tabular}

activation energy to different extents depending on the method of preparation. Surface area decreased sharply with rutilation. During calcination $\mathrm{Fe}_{2} \mathrm{O}_{3}$ reacts with $\mathrm{TiO}_{2}$ to form pseudo brookite.

\section{$7.2 \mathrm{NiO}$ doped $\mathrm{TiO}_{2}$}

Chemical analysis revealed that the samples of $\mathrm{NiO}$ doped $\mathrm{TiO}_{2}$ prepared by co-precipitation and wetimpregnation contain $18.8 \%$ and $17.91 \%$ of $\mathrm{NiO}$, respectively. The $\mathrm{TiO}_{2}$ contents were 80.92 and $81 \cdot 32 \%$, 

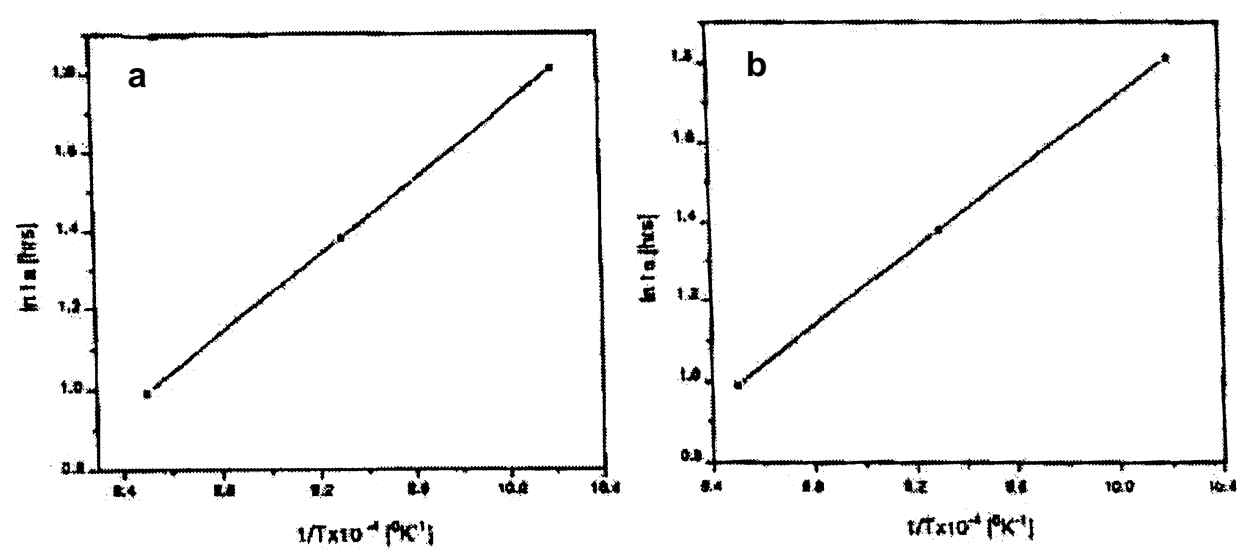

Figure 5. a. Plot of $\ln t \alpha$ against $1 / T$ for co-precipitated $\mathrm{NiO} / \mathrm{TiO}_{2}$ samples and b. plot of $\ln t \alpha$ against $1 / T$ for wet-impregnated $\mathrm{NiO} / \mathrm{TiO}_{2}$ samples.

Table 4. Surface area of $\mathrm{NiO} / \mathrm{TiO}_{2}$ samples prepared by coprecipitation and wet-impregnation.

\begin{tabular}{lcc}
\hline & \multicolumn{2}{c}{ Surface area $\left(\mathrm{m}^{2} / \mathrm{g}\right)$} \\
\cline { 2 - 3 } Method of preparation & $\begin{array}{c}\text { Before } \\
\text { calcination }\end{array}$ & $\begin{array}{c}\text { After calcination } \\
\text { at } 700^{\circ} \mathrm{C} / 8 \mathrm{~h}\end{array}$ \\
\hline Co-precipitation & $416 \cdot 18$ & $17 \cdot 86$ \\
Wet-impregnation & $403 \cdot 1$ & $18 \cdot 27$ \\
\hline
\end{tabular}

respectively. XRD patterns of calcined samples prepared by co-precipitation and wet-impregnation are shown in figures $4 \mathrm{a}$ and $\mathrm{b}$, respectively.

It was observed that rutilation increased with increase of temperature. In all the samples there were peaks corresponding to anatase, rutile and nickel titanate. There were no peaks for $\mathrm{NiO}$. Hence $\mathrm{NiO}$ reacted with $\mathrm{TiO}_{2}$ during calcination to form nickel titanate. The percentage of rutile formed in co-precipitated and wet-impregnated samples calcined at different temperatures and durations are shown in tables $3 a$ and $b$, respectively.

It was found that the percentage of rutile is higher in co-precipitated samples than that of wet-impregnated ones at a given condition. It is due to lower distribution of $\mathrm{NiO}$ on $\mathrm{TiO}_{2}$ compared with that in co-precipitated ones. However, the variation in rutilation was found to be higher than that reported for undoped $\mathrm{TiO}_{2}$ (Gennari and Pasquevich 1998) which is due to the presence of $\mathrm{NiO}$.

The activation energy for anatase-rutile transformation as calculated from the slope of the plot shown in figures $5 \mathrm{a}$ and $b$ gave a value of $6.62 \mathrm{k} . \mathrm{cal} / \mathrm{mol}$ for co-precipitated sample and $10.33 \mathrm{k} . c a l / \mathrm{mol}$ for wet-impregnated sample against a reported value of $90 \mathrm{k} . \mathrm{cal} / \mathrm{mol}$ for pure anatase (Gennari and Pasquevich 1998).

The lowering of activation energy is higher in co-precipitated samples as compared to that of wetimpregnated samples. It would be due to uniform distri- bution of $\mathrm{NiO}$ on $\mathrm{TiO}_{2}$ in co-precipitated samples as compared to wet-impregnated ones.

The surface area measurements shown in table 4 reveal that the surface area decreases drastically on rutilation. Here also the decrease is higher in co-precipitated samples due to higher rutilation.

Scanning electron micrographs of calcined samples prepared by co-precipitation and wet-impregnation are shown in figures $6 a$ and $b$.

It was found that the particles were very fine and much less agglomerated in wet-impregnated samples as compared to co-precipitated ones. Lower rutile percentage in wet-impregnated samples could be the reason as mentioned earlier. Particles were found to be approximately similar in size and shape in each sample. No separate $\mathrm{NiO}$ particles could be seen in any of the micrographs. Hence it is obvious that $\mathrm{NiO}$ has reacted with $\mathrm{TiO}_{2}$ on calcination. XRD studies also support these observations.

It was also found that the enhancement of rutilation by $\mathrm{NiO}$ is higher than that for $\mathrm{Fe}_{2} \mathrm{O}_{3}$ even though both enhance rutilation by calcination at higher temperature and durations. $\mathrm{NiO}$ would be increasing oxygen vacancies in $\mathrm{TiO}_{2}$ crystal lattice to higher extents than $\mathrm{Fe}_{2} \mathrm{O}_{3}$. These oxygen vacancies are responsible for the enhancement of transformation and lowering of activation energy as reported earlier (Gennari and Pasquevich 1998). 

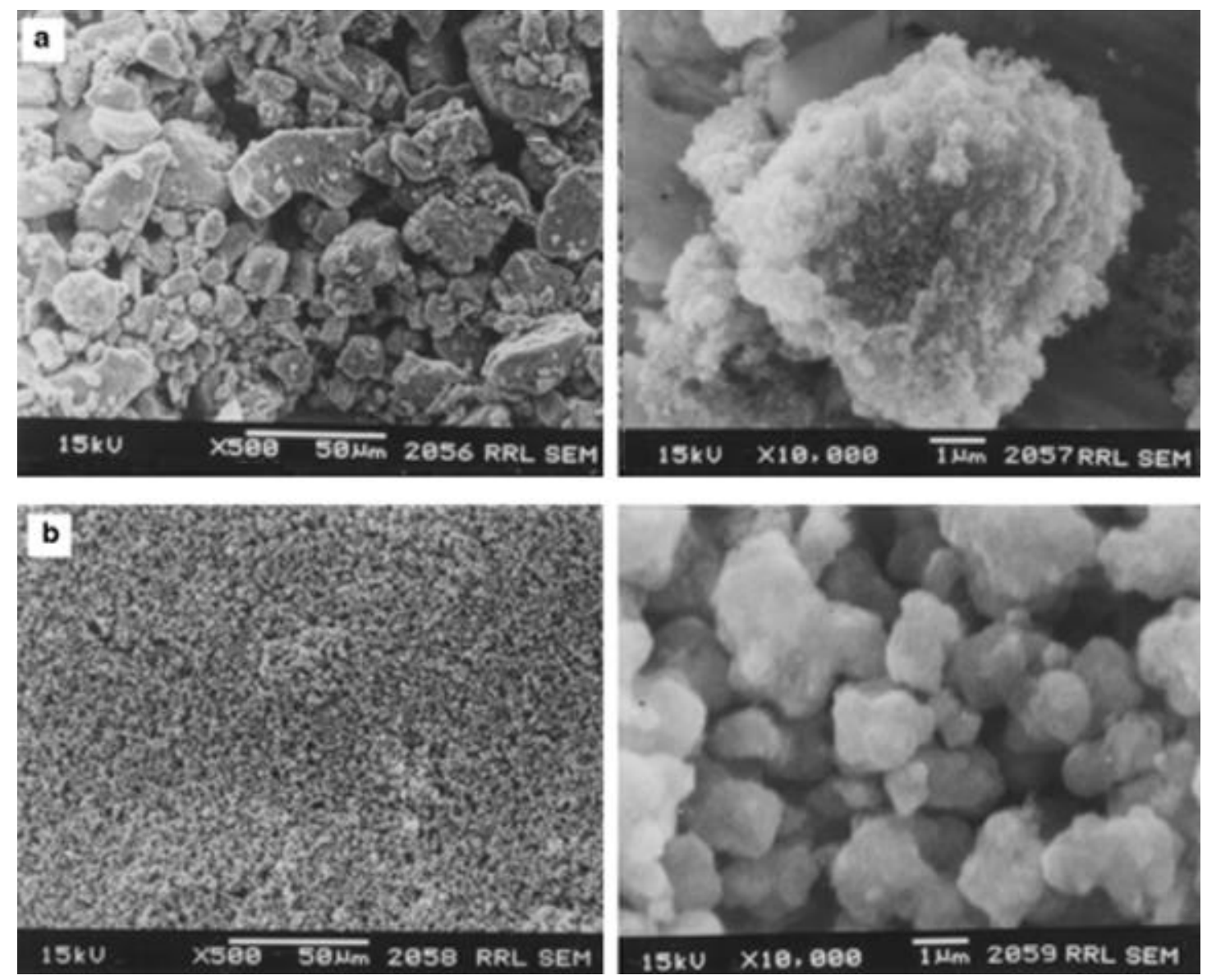

Figure 6. a. $\mathrm{SEM}$ of co-precipitated $\mathrm{NiO} / \mathrm{TiO}_{2}$ samples calcined at $700^{\circ} \mathrm{C}$ for $8 \mathrm{~h}$ and b. wet-impregnated $\mathrm{NiO} / \mathrm{TiO}_{2}$ samples calcined at $700^{\circ} \mathrm{C}$ for $8 \mathrm{~h}$.

\section{Conclusions}

The following conclusions can be drawn from this investigation.

Anatase-rutile transformation is enhanced by the presence of both $\mathrm{NiO}$ and $\mathrm{Fe}_{2} \mathrm{O}_{3}$ in the order $\mathrm{NiO}>$ $\mathrm{Fe}_{2} \mathrm{O}_{3}$. XRD analysis proved that rutilation is increased on increasing temperature and duration of calcination. Also both $\mathrm{NiO}$ and $\mathrm{Fe}_{2} \mathrm{O}_{3}$ react with $\mathrm{TiO}_{2}$ during calcination to form corresponding titanates. Method of preparation has a significant influence on quantity of rutile formed during calcination, since co-precipitated samples gave higher rutile \% than wet-impregnated ones at any temperature and time of calcinations. The activation energy is lowered much, on doping with $\mathrm{Fe}_{2} \mathrm{O}_{3}$ and $\mathrm{NiO}$, than for pure anatase in the order $\mathrm{NiO}>\mathrm{Fe}_{2} \mathrm{O}_{3}$. Surface area measurements confirmed that the surface area decreased markedly upon rutilation.

\section{Acknowledgement}

We would like to express our sincere thanks to Dr G Vijay Nair, Director, Regional Research Laboratory
(CSIR), Thiruvananthapuram, for providing necessary facilities.

\section{References}

A Status report prepared under the National Register of Foreign Collaborations, Govt of India 1993 Technology in Indian titanium dioxide industry

Gennari F C and Pasquevich D M 1998 J. Mater. Sci. 33 1571

Gennari F C and Pasquevich D M 1999 J. Am. Ceram. Soc. 82 1915

Hiemenz 1986 Principles of colloids and surface chemistry (New York and Basel: Marcel Dekker, Inc.) 2nd edn

Kolthoff J M, Elving P J and Sandell E B 1961 Treat. Anal. Chem. 549

Kolthoff J M, Elving P J and Sandell E B 1962 Treat. Anal. Chem. 5 275, 404

Mackenzie K J D 1975 Trans. J. Br. Ceram. Soc. 74 29, 77

Rao C N R, Turner A and Honing J M 1959 J. Phys. Chem. Solids 11473

Shannon R D and Pask J A 1965 J. Am. Ceram. Soc. 48391

Yoganarasimhan S R and Rao C N R 1962 Trans. Faraday Soc. 581571 